\title{
Proposal of Two New Species in the Genus Microbacterium: Microbacterium dextranolyticum sp. nov. and Microbacterium aurum sp. nov.
}

\author{
AKIRA YOKOTA, ${ }^{1 *}$ MARIKO TAKEUCHI, ${ }^{1}$ AND NOBERT WEISS ${ }^{2}$ \\ Institute for Fermentation, Osaka, 17-85, Juso-honmachi 2-chome, Yodogawa-ku, Osaka 532, \\ Japan, ${ }^{1}$ and Deutsche Sammlung von Mikroorganismen und Zellkulturen \\ D-3300 Braunschweig, Germany ${ }^{2}$
}

\begin{abstract}
The taxonomic positions of Flavobacterium sp. strain IFO $14592^{\mathrm{T}}\left(=\mathrm{M}-73^{\mathrm{T}}\right)(\mathrm{T}=$ type strain), a dextran- $\alpha-1,2$-debranching enzyme producer, and Microbacterium sp. strain IFO $\left.15204^{\mathrm{T}}\left(=\mathrm{H}_{-5}\right)^{\mathrm{T}}\right)$, an isolate obtained from corn steep liquor, were investigated; on the basis of the results of chemotaxonomic and phenetic studies and DNA-DNA similarity data, we propose that these bacteria should be classified in the genus Microbacterium as Microbacterium dextranolyticum sp. nov. and Microbacterium aurum sp. nov., respectively. The type strain of $M$. dextranolyticum is strain IFO 14592, and the type strain of $M$. aurum is strain IFO 15204.
\end{abstract}

The genus Microbacterium was proposed by Orla-Jensen (15), and its description was emended by Collins et al. (1). Four species have been described previously: Microbacterium lacticum, Microbacterium imperiale, Microbacterium laevaniformans, and Microbacterium arborescens $(1,5,6)$.

During a taxonomic study of Flavobacterium strains in the Institute for Fermentation at Osaka (IFO) culture collection, we found that Flavobacterium sp. strain IFO $14592^{\mathrm{T}}$ (= $\left.M-73^{\mathrm{T}}\right)(\mathrm{T}=$ type strain), a dextran- $\alpha$-1,2-debranching enzyme producer $(8,13)$, and strain IFO $15204^{\mathrm{T}}\left(=\mathrm{H}-5^{\mathrm{T}}\right)$, an isolate obtained from corn steep liquor, belong to the genus Microbacterium (21). To determine the taxonomic positions of these organisms, we examined their physiological and chemotaxonomic characteristics and compared these characteristics with those of previously described species of the genus Microbacterium.

In this paper we describe characterization of these two strains and propose that they are representatives of two new species of the genus Microbacterium on the basis of the results of chemotaxonomic, phenetic, and DNA-DNA hybridization studies.

\section{MATERIALS AND METHODS}

Bacterial strains and culture conditions. The bacterial strains which we studied are listed in Table 1 . In addition to the type strains, reference strains of $M$. lacticum and $M$. laevaniformans were included. All strains were cultured at $28^{\circ} \mathrm{C}$ with aerobic shaking in a peptone-yeast extract medium supplemented with brain heart infusion (PY-BHI medium), which contained $1 \%$ peptone, $0.2 \%$ yeast extract, $0.2 \%$ Bacto brain heart infusion (Difco Laboratories), $0.2 \% \mathrm{NaCl}$, and $0.2 \%$ D-glucose (pH 7.2). Cells were harvested by centrifugation, washed with water, and then lyophilized.

Morphological and phenotypic characteristics. Cell morphology was determined by using cells grown on PY-BHI medium. Motility was determined with a light microscope by the hanging drop method. Unless otherwise indicated, all tests were carried out at $28^{\circ} \mathrm{C}$. Catalase activity was determined by bubble formation in a $3 \%$ hydrogen peroxide solution. Oxidase activity was determined by the oxidation

\footnotetext{
* Corresponding author.
}

of $1 \%$ tetramethyl-p-phenylenediamine on filter paper. Acid production from carbohydrates was studied in a medium containing $0.3 \%$ peptone, $0.25 \% \mathrm{NaCl}, 0.003 \%$ bromcresol purple, and $0.5 \%$ carbohydrate $(\mathrm{pH} \mathrm{7.2)}$. Assimilation of organic acids was studied in a medium containing $0.5 \%$ organic acid (sodium salt), $0.02 \%$ D-glucose, $0.01 \%$ yeast extract, $0.01 \%$ peptone, $0.01 \%$ Bacto brain heart infusion, $0.01 \% \mathrm{~K}_{2} \mathrm{HPO}_{4}, 0.5 \% \mathrm{NaCl}, 2 \%$ agar, and $12 \mathrm{ppm}$ of phenol red $(\mathrm{pH} 7.0)$. Nitrate reduction and hydrolysis of starch, gelatin, casein, and esculin were tested by the methods described by Cowan and Steel (2).

Peptidoglycan analysis. Cell walls were prepared from ca. $500 \mathrm{mg}$ (dry weight) of cells by mechanical disruption with an ultrasonic oscillator and were purified as described by Schleifer and Kandler (18). The amino acid compositions of complete wall hydrolysates were determined with a model LC-6AD high-performance liquid chromatography (HPLC) apparatus (Shimadzu Co., Ltd., Kyoto, Japan) equipped with a Wakopak WS-PTC column (Wako Pure Chemical Industries, Ltd., Osaka, Japan) as phenylthiocarbamoyl derivatives according to the manufacturer's instructions (23). The amino acid compositions were determined by two-dimensional descending chromatography on cellulose thin-layer chromatography (TLC) plates (Tokyo Kasei Co., Ltd., Tokyo, Japan) by the method of Harper and Davis (4). The configurations of the amino acids were determined by measuring the amino acid contents of the hydrolysates before and after incubation with $\mathrm{D}$ - and L-amino acid oxidase (alanine and serine), L-lysine decarboxylase (lysine), or L-glutamic acid decarboxylase (glutamic acid), as described by Kandler and König (7).

The peptidoglycan structure was determined by the method of Schleifer and Kandler (18). Partial acid hydrolysates were examined by two-dimensional TLC, and peptides were identified on the basis of their chromatographic mobilities and staining characteristics (18). The $\mathrm{N}$-terminal amino acid of the interpeptide bridge was determined by dinitrophenylation of the undegraded peptidoglycan (18).

Cell wall sugar analysis. Cell walls were hydrolyzed with 2 $\mathrm{N} \mathrm{HCl}$ at $100^{\circ} \mathrm{C}$ for $2 \mathrm{~h}$, dried in vacuo, and then analyzed by the method of Mikami and Ishida (10) by using an HPLC apparatus (model LC-5A; Shimadzu Co., Ltd.) equipped with a Shim-pack ISA $07 / \mathrm{S} 2504$ column $(250$ by $4 \mathrm{~mm})$ and a Shimadzu model RE-530 spectrofluorometer (20). 
TABLE 1. Bacterial strains used

\begin{tabular}{|c|c|c|c|c|}
\hline Species & Strain (IFO no.) & Other designation $(\mathrm{s})^{a}$ & Reference and/or source & Proposed reclassification \\
\hline M. lacticum & $14135^{T}$ & ATCC $8180^{\mathrm{T}}$ & & \\
\hline M. lacticum & 14137 & ATCC 8181 & & \\
\hline M. lacticum & 14138 & ATCC 49094 & & \\
\hline M. laevaniformans & $14471^{\mathrm{T}}$ & ATCC $15953^{\mathrm{T}}$ & & \\
\hline M. laevaniformans & 15234 & NCFB 2288, ATCC 49090 & 14 & Aureobacterium sp. \\
\hline M. laevaniformans & 15235 & NCFB 2289, ATCC 49091 & 14 & Aureobacterium sp. \\
\hline M. imperiale & $12610^{\mathrm{T}}$ & ATCC $8365^{\mathrm{T}}$ & & \\
\hline M. arborescens & $3750^{\mathrm{T}}$ & ATCC $4358^{\mathrm{T}}$ & & \\
\hline Flavobacterium sp. & $14592^{\mathrm{T}}$ & $M-73^{\mathrm{T}}$ & Soil $(8,13)$ & M. dextranolyticum $\mathrm{sp}$. nov. \\
\hline Microbacterium sp. & $15204^{\mathrm{T}}$ & $\mathrm{H}-5^{\mathrm{T}}$ & Corn steep liquor (this study) & $M$. aurum sp. nov. \\
\hline
\end{tabular}

${ }^{a}$ ATCC, American Type Culture Collection, Rockville, Md.; NCFB, National Collection of Food Bacteria, AFRC Institute of Food Research Reading Laboratory, Shinfield, Reading, England.

Glycolyl analysis. Glycolate tests were performed by using the method described by Uchida and Aida (22).

Analysis of cellular fatty acids. Fatty acids were extracted from dry cells $(50 \mathrm{mg})$ by acid methanolysis and were examined by using a model GC-9A gas-liquid chromatography apparatus (Shimadzu Co., Ltd.) equipped with a glass column $(0.2 \mathrm{~cm}$ by $5 \mathrm{~m})$ containing $10 \%$ diethyleneglycol succinate on Chromosorb $\mathrm{W}$ at $180^{\circ} \mathrm{C}$ (19).

Analysis of polar lipids. Free lipids were extracted from dry cells $(100 \mathrm{mg})$, purified by the method of Minnikin et al. (12), and examined by two-dimensional TLC, using Kieselgel $60 \mathrm{~F}_{254}$ plates. Lipids were visualized by spraying the plates with $10 \%$ molybdophosphoric acid in ethanol, followed by heating at $140^{\circ} \mathrm{C}$ for $10 \mathrm{~min}$. The following specific spray reagents were also used: $\alpha$-naphthol for sugars and ninhydrin for amino groups.

Analysis of mycolic acids. Mycolic acids were analyzed by the method of Minnikin et al. (11).

Analysis of isoprenoid quinones. Menaquinones were extracted from dry cells $(200 \mathrm{mg})$ with chloroform-methanol (2:1, vol/vol), purified by TLC (using benzene as the solvent), extracted with diethyl ether, dried under a nitrogen stream, and then analyzed by HPLC by using a Shimadzu model LC-5A instrument equipped with a Zorbax octyldecyl silane column ( 4.6 by $150 \mathrm{~mm})$.

DNA base composition. DNA was obtained by the method of Saito and Miura (16). The $\mathrm{G}+\mathrm{C}$ content of DNA was determined by the method of Mesbah et al. (9) after treatment with $P_{1}$ nuclease and alkaline phosphatase and by HPLC by using a model LC-6AD instrument (Shimadzu Co., Ltd.) equipped with a Cosmosil $5 \mathrm{C}_{18}$ - AR column ( 4.6 by 150 mm; Nacalai Tesque, Inc., Tokyo, Japan).

DNA-DNA hybridization. DNA-DNA hybridization was carried out fluorometrically in microdilution wells by using biotinylated DNA (3).

\section{RESULTS AND DISCUSSION}

Morphological, physiological, and biochemical characteristics. Both strains were gram-positive, nonmotile rods, and the cells were arranged in $\mathrm{V}$ formations. Colonies on PYBHI agar were yellow. Strain IFO $14592^{\mathrm{T}}$ exhibited good growth aerobically on nutrient agar and produced acid from many carbohydrates. Strain IFO $15204^{\mathrm{T}}$ grew poorly on nutrient agar and produced acid only from D-galactose, sucrose, trehalose, raffinose, and inulin.

Chemotaxonomic characteristics. The chemotaxonomic characteristics of the two strains are summarized in Table 2. The amino acid analysis and determination of the configurations of the amino acids in the cell wall hydrolysates revealed the presence of $\mathrm{D}$-alanine, D-glutamic acid plus hydroxyglutamic acid, glycine, and L-lysine (molar ratio, ca. $1: 1: 2: 2$ ) in strain IFO $14592^{\mathrm{T}}$ and $D$-alanine, D-glutamic acid plus hydroxyglutamic acid, L-homoserine, D-lysine, and

TABLE 2. Chemotaxonomic characteristics of Microbacterium strains ${ }^{a}$

\begin{tabular}{|c|c|c|c|c|c|c|}
\hline Species & $\begin{array}{c}\text { Strain } \\
\text { (IFO no.) }\end{array}$ & $\begin{array}{l}\mathrm{G}+\mathrm{C} \\
\text { content } \\
\text { (mol\%) }\end{array}$ & Menaquinone(s) & $\begin{array}{c}\text { Peptidoglycan } \\
\text { type }\end{array}$ & $\begin{array}{l}\text { Amino acid(s) } \\
\text { in cell wall }\end{array}$ & Cell wall sugars ${ }^{c}$ \\
\hline M. lacticum & $14135^{\mathrm{T}}$ & 70.0 & MK-11, MK-12 & $\mathrm{B} 1 \alpha$ & L-Lys & Rha, Man, Gal \\
\hline M. lacticum & 14137 & 69.0 & MK-11, MK-12 & $\mathrm{B} 1 \alpha$ & L-Lys & Rha, (Man), Gal \\
\hline M. lacticum & 14138 & 69.8 & MK-11, MK-12 & $\mathrm{B} 1 \alpha$ & L-Lys & Rha, Man, Gal \\
\hline M. laevaniformans & $14471^{\mathrm{T}}$ & 70.5 & MK-11, MK-12 & $B 1 \alpha$ & L-Lys & Rha, Man, Gal, Xyl \\
\hline M. laevaniformans & 15234 & 70.3 & MK-12 & B $2 \beta$ & L-Hsr, D-Orn & Rha, Fuc, Gal \\
\hline M. laevaniformans & 15235 & 70.1 & MK-12 & $\mathrm{B} 2 \beta$ & L-Hsr, D-Orn & Rha, Fuc, Gal \\
\hline M. imperiale & $12610^{\mathrm{T}}$ & 71.2 & MK-11, MK-12 & $\mathrm{B} 1 \beta$ & L-Hsr, D-Lys & Rha, Man, Gal \\
\hline M. arborescens & $3750^{\mathrm{T}}$ & 71.0 & MK-11, MK-12 & $\mathrm{B} 1 \beta$ & L-Hsr, D-Lys & 6dTal, Man, Gal \\
\hline M. dextranolyticum & $14592^{\mathrm{T}}$ & 68.3 & MK-11, MK-12 & $B 1 \alpha$ & L-Lys & 6dTal, Man, Gal \\
\hline M. aurum & $15204^{\mathrm{T}}$ & 69.2 & MK-11, MK-12 & $\mathbf{B} 1 \beta$ & L-Hsr, D-Lys & Fuc, Gal, Glc \\
\hline
\end{tabular}

${ }^{a}$ The data for the type strains of previously described species are from reference 1. All strains contained 12-methyltetradecanoic acid, 14-methylpentadecanoic acid, and 14-methylhexadecanoic acid as major cellular fatty acids. All strains contained the following polar lipids: diphosphatidylglycerol, phosphatidylglycerol, and glycolipid. None of the strains contained mycolic acid, and all strains contained cell wall glycolyl groups.

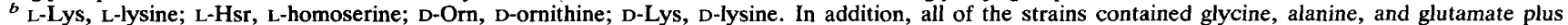
3-hydroxyglutamate.

C Rha, rhamnose; Gal, galactose; Glc, glucose; Man, mannose; 6dTal, 6-deoxytalose; Xyl, xylose; Fuc, fucose. Parentheses indicate that a trace amount is present. 


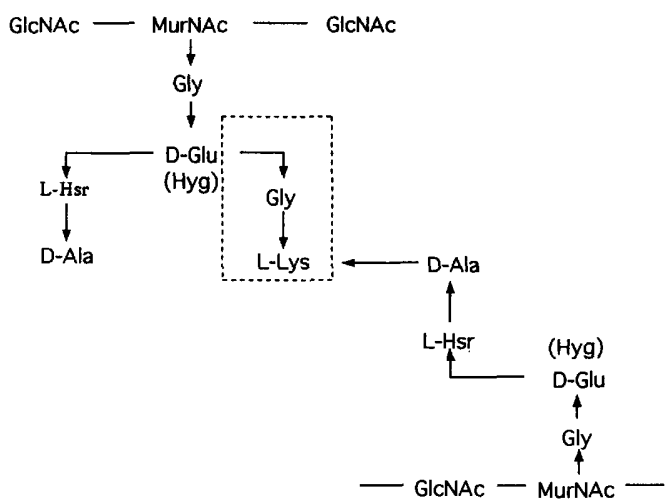

FIG. 1. Proposed structure of the peptidoglycan of $M$. aurum IFO $15204^{\mathrm{T}}$. Abbreviations: Gly, glycine; D-Glu, D-glutamic acid; Hyg, 3-hydroxyglutamic acid; L-Hsr, L-homoserine; D-Ala, D-alanine; L-Lys, L-lysine; GlcNAc, $N$-acetylglucosamine; MurNAc, $N$-acetylmuramic acid. The interpeptide bridge is enclosed by a dashed line.

glycine (molar ratio, ca. 1:1:1:2:1) in strain IFO $15204^{\mathrm{T}}$. Homoserine was not present in strain IFO $14592^{\mathrm{T}}$.

The peptidoglycan studies of Schleifer (17) and Schleifer and Kandler (18) showed that the species included in the genus Microbacterium contain the $B 1 \alpha$ and $B 1 \beta$ types of peptidoglycan. An analysis of the amino acid compositions of their cell walls suggested that strains IFO $14592^{\mathrm{T}}$ and IFO $15204^{\mathrm{T}}$ contain the $\mathrm{B} 1 \alpha$ and $\mathrm{B} 1 \beta$ peptidoglycan types, respectively. An examination of the primary structures indicated that the peptidoglycan in strain IFO $14592^{\mathrm{T}}$ is the usual B1 $\alpha$ type (data not shown), but that the peptidoglycan in strain IFO $15204^{\mathrm{T}}$ is B1 $\beta$ type (Fig. 1), except that the structure of the interpeptide bridge is slightly different from the structures of the interpeptide bridges in the previously described species $M$. imperiale (18) and $M$. arborescens (data not shown) because these two species contain 2 mol of glycine residues in the interbridge unit, whereas strain IFO $15204^{\mathrm{T}}$ contains only $1 \mathrm{~mol}$. Both strain IFO $14592^{\mathrm{T}}$ and strain IFO $15204^{\mathrm{T}}$ possess high levels of glycolate in the glycan moiety of the cell walls, which suggests that muramic acid occurs in the $\mathrm{N}$-glycolyl form rather than the more common $\mathrm{N}$-acetyl form. Mycolic acids are not present in these strains. The cell wall sugars 6-deoxytalose, galactose, and glucose were detected in strain IFO $14592^{\mathrm{T}}$, and fucose, galactose, and glucose were detected in strain IFO $15204^{\mathrm{T}}$. The two strains had very similar fatty acid profiles, composed primarily of anteiso-methyl branched acids, anteiso$C_{15: 0}$, and anteiso- $C_{17: 0}$, and both possessed long unsaturated menaquinones (11 and 12 isoprene units). In the two-dimensional TLC analysis of the polar lipids, diphosphatidylglycerol, phosphatidylglycerol, and an unidentified glycolipid were detected in the extracts of both strains. The DNA base compositions of strains IFO $14592^{\mathrm{T}}$ and IFO $15204^{\mathrm{T}}$ were 68.3 and $69.2 \mathrm{~mol} \%$, respectively.

On the basis of the chemotaxonomic characteristics described above, both strains were identified as members of the genus Microbacterium and could be differentiated from members of the genera Curtobacterium and Aureobacterium and all other coryneform genera described previously (Table 3).

A chemotaxonomic study of the reference strains of $M$. laevaniformans, IFO 15234 (= NCFB 2288) and IFO 15235 (= NCFB 2289), revealed that they have DNA G+C con- tents and cellular fatty acid compositions similar to those other species of the genus Microbacterium, but differ in their menaquinone compositions and the amino acid compositions of their peptidoglycans (Table 2). These findings indicate that these organisms should be excluded from the genus Microbacterium and should probably be assigned to the genus Aureobacterium.

DNA-DNA relatedness. As shown in Table 4, the levels of DNA-DNA similarity between strains IFO $14592^{\mathrm{T}}$ and IFO $15204^{\mathrm{T}}$ and the type strains of the previously described species of the genus Microbacterium were low.

Phenotypic differentiation. The results described above indicate that each of the new strains constitutes a separate taxon. Differential characteristics of these strains and the four previously described species of the genus Microbacterium are summarized in Table 5 .

The description of the genus Microbacterium was emended by Collins et al. (1). The members of this genus are characterized by the presence of L-lysine (and L-homoserine) in the cell walls (B1 $\alpha$ or B1 $\beta$ type of peptidoglycan), by the presence of a glycine in the interpeptide bridge, by the presence of $\mathrm{N}$-glycolyl residues in the cell walls, by having isoprenoid menaquinones with 11 and 12 isoprene units, by $\mathrm{G}+\mathrm{C}$ values of 66 to $69 \mathrm{~mol} \%$, and by slow and weak acid production from sugars. On the basis of biochemical and chemical criteria, strains IFO $14592^{\mathrm{T}}$ and IFO $15204^{\mathrm{T}}$ can be distinguished readily from all previously described species of the genus Microbacterium and in our opinion warrant status as new taxa; therefore, we propose that these organisms should be classified as new species in the genus Microbacterium, Microbacterium dextranolyticum sp. nov. and $M i$ crobacterium aurum sp. nov., respectively.

Description of Microbacterium dextranolyticum sp. nov. Microbacterium dextranolyticum (dex.tra.no.ly'ti.cum. Engl. n. dextran, polysaccharide produced by bacteria; Gr. adj. lyticum, dissolving; dextranolyticum, dextran dissolving). Good growth occurs on solid media in air; colonies are 2 to $4 \mathrm{~mm}$ in diameter, circular, low convex with entire margins, opaque, and moist. A yellow pigment is produced. In young cultures, small, slender rods are formed. Many cells are arranged at angles, forming V shapes; primary branching is uncommon. In older cultures rods are shorter, but a marked rod-coccus growth cycle does not occur. Gram-positive rods that are not acid fast and not motile. Endospores are not formed. The optimum growth temperature is ca. $30^{\circ} \mathrm{C}$. Good aerobic growth. Acid is produced weakly from glucose, mannose, fructose, maltose, cellobiose, mannitol, xylose, L-arabinose, galactose, sucrose, lactose, trehalose, raffinose, inulin, arbutin, esculin, ethanol, butanol, melibiose, and melezitose, but not from ribose, D-arabinose, L-sorbose, xylitol, erythritol, adonitol, dulcitol, sorbitol, inositol, methanol, $\alpha$-methyl-D-glucoside, L-rhamnose, starch, glycerol, and salicin. Pyruvate, fumarate, and succinate are assimilated, but acetate, lactate, malate, $\alpha$-ketoglutarate, maleate, formate, butyrate, oxalate, pimelate, glycolate, glyoxylate, gluconate, propionate, and hippurate are not assimilated. Esculin, Tween 20, Tween 40, Tween 60, and Tween 80 are hydrolyzed, but gelatin and starch are not hydrolyzed. Urease negative. $\mathrm{H}_{2} \mathrm{~S}$ is produced. Voges-Proskauer reaction positive. Arginine is not decarboxylated.

The cell wall peptidoglycan contains L-lysine as the diamino acid (variation B1 $\alpha$ ). The glycan moiety of the cell wall contains glycolyl and acetyl residues. The cell wall sugars are rhamnose, 6-deoxytalose, galactose, and glucose. Mycolic acid is not present. The nonhydroxylated fatty acids are primarily anteiso- and iso-methyl branched acids. The 
TABLE 3. Distinguishing chemotaxonomic features of coryneform taxa

\begin{tabular}{|c|c|c|c|c|c|c|c|}
\hline Taxon & $\begin{array}{l}\text { Wall di- } \\
\text { amino acid }\end{array}$ & $\begin{array}{l}\text { Murein } \\
\text { type }^{b}\end{array}$ & $\begin{array}{l}\mathrm{G}+\mathrm{C} \\
\text { content } \\
\text { (mol\%) }\end{array}$ & $\begin{array}{l}\text { Mycolic } \\
\text { acids }\end{array}$ & $\begin{array}{l}\text { Fatty acid } \\
\text { types }^{c, d}\end{array}$ & Major menaquinone(s) & Polar lipids $^{d, e}$ \\
\hline Agromyces & L-DAB & $\mathrm{B} 2 \gamma$ & $71-76$ & - & S, A, I & $\begin{array}{l}\text { MK-11, MK-12, } \\
\text { MK-13 }\end{array}$ & DPG, PG, GL \\
\hline Arcanobacterium & Lys & A & $48-52$ & - & $\mathrm{S}, \mathrm{U}$ & MK-9(- $\left.\mathrm{H}_{4}\right)$ & ND \\
\hline Arthrobacter (globiformis group) & L-Lys & $\mathrm{A} 3 \alpha$ & $59-69$ & - & $\mathrm{S}, \mathrm{A}, \mathrm{I}$ & MK-9(- $\left.\mathbf{H}_{2}\right)$ & DPG, PG, (PI), GL \\
\hline Arthrobacter (nicotianae group) & L-Lys & $\mathrm{A} 4 \alpha$ & $59-69$ & - & $\mathrm{S}, \mathrm{A}, \mathrm{I}$ & MK-8, MK-9 & DPG, PG, (PI), GL \\
\hline Aureobacterium & D-Orn & $\mathbf{B} 2 \beta$ & $67-70$ & - & $\mathrm{S}, \mathrm{A}, \mathrm{I}$ & $\begin{array}{l}\text { MK-11, MK-12, } \\
\text { MK-13, MK-14 }\end{array}$ & DPG, PG, GL \\
\hline Brachybacterium & meso-DAP & $\mathrm{A} 4 \gamma$ & $68-72$ & - & $\mathrm{S}, \mathrm{A}, \mathrm{I}$ & MK-7 & DPG, PG, GL \\
\hline Brevibacterium & meso-DAP & $\mathrm{Al} \gamma$ & $60-67$ & - & $\mathrm{S}, \mathrm{A}, \mathrm{I}$ & $\begin{array}{l}\mathrm{MK}-8\left(\mathrm{H}_{2}\right), \mathrm{MK}- \\
\quad 7\left(\mathrm{H}_{2}\right)\end{array}$ & DPG, PG, (PI), GL \\
\hline Cellulomonas & L-Orn & $\mathrm{A} 4 \beta, \mathrm{A} 4 \alpha$ & $71-76$ & - & $\mathrm{S}, \mathrm{A}, \mathrm{I}$ & MK-9 $\left(\mathrm{H}_{4}\right)$ & DPG, PI, PGL \\
\hline Corynebacterium & meso-DAP & $\mathrm{A} 1 \gamma$ & $51-65$ & + & $\mathrm{S}, \mathrm{U},(\mathrm{T})$ & $\begin{array}{l}\text { MK- } 9\left(\mathrm{H}_{2}\right), \text { MK- } \\
8\left(\mathrm{H}_{2}\right)\end{array}$ & DPG, PI, PIDM, (PG), (GL) \\
\hline Clavibacter & L-DAB & $\mathrm{B} 2 \gamma$ & $67-78$ & - & $\mathrm{S}, \mathrm{A}, \mathrm{I}$ & MK-10, MK-9 & DPG, PG, GL \\
\hline Curtobacterium & D-Orn & $\mathrm{B} 2 \beta$ & $68-75$ & - & S, A, I & MK-9 & DPG, PG, GLs \\
\hline Exiguobacterium & Lys & A & $53-56$ & - & $\mathrm{S}, \mathrm{A}, \mathrm{I}, \mathrm{U}$ & MK-7 & DPG, PG, PE \\
\hline Jonesia & Lys & A & $58-59$ & - & $\mathrm{S}, \mathrm{A}, \mathrm{I}$ & MK-9 & DPG, PI, PGL \\
\hline Microbacterium & L-Lys & $\mathrm{B} 1 \alpha, \mathrm{B} 1 \beta$ & $69-75$ & - & $\mathrm{S}, \mathrm{A}, \mathrm{I}$ & MK-11, MK-12 & DPG, PG, GL, (PGL) \\
\hline Nocardioides & LL-DAP & $\mathrm{A} 3 \gamma$ & $69-72$ & - & $\begin{array}{c}\mathrm{S}, \mathrm{A}, \mathrm{I}, \mathrm{U}, \mathrm{T}, \\
2-\mathrm{OH}\end{array}$ & $\underset{9\left(\mathrm{H}_{4}\right)}{\mathrm{MK}-8\left(\mathrm{H}_{4}\right), \mathrm{MK}-}$ & $\mathrm{DPG}, \mathrm{PG}, \mathrm{OH}-\mathrm{PG}$ \\
\hline Terrabacter & LL-DAP & $\mathrm{A} 3 \gamma$ & $69-72$ & - & $\mathrm{S}, \mathrm{A}, \mathrm{I}, \mathrm{U}$ & $\mathrm{MK}-8\left(\mathrm{H}_{4}\right)$ & DPG, PE, PL, PGL \\
\hline Aeromicrobium & LL-DAP & $\mathrm{A} 3 \gamma$ & 70 & - & $\mathrm{S}, \mathrm{U}, \mathrm{T}$ & None & ND \\
\hline Rarobacter & L-Orn & A & $65-66$ & - & $\mathrm{S}, \mathrm{A}, \mathrm{I}$ & MK-9 & ND \\
\hline Renibacterium & L-Lys & $\mathrm{A} 3 \alpha$ & $52-54$ & - & $\mathrm{S}, \mathrm{A}, \mathrm{I}$ & MK-9, MK-10 & DPG, GL \\
\hline Rubrobacter & L-Lys & $\mathrm{A} 3 \alpha$ & 68 & - & $12-\mathrm{H}, \mathrm{A}, 2-\mathrm{OH}$ & MK-8 & DPG, PG, PL, PGL, GL \\
\hline
\end{tabular}

${ }^{a}$ L-DAB, L-diaminobutyric acid; Lys, lysine; L-Lys, L-lysine; D-Orn, D-ornithine; L-Orn, L-ornithine; meso-DAP, meso-diaminopimelic acid; LL-DAP, LL-diaminopimelic acid.

${ }^{b}$ Murein type as described by Schleifer and Kandler (18).

c S, straight-chain saturated; A, anteiso-methyl branched; I, iso-methyl branched; U, monounsaturated; T, tuberculostearic acid; 12-H, 12-methylhexadecanoic acid; 2-OH, 2-hydroxylated fatty acids.

${ }^{d}$ Parentheses indicate that a compound may or may not be present.

e DPG, diphosphatidylglycerol; PG, phosphatidylglycerol; GL, glycolipid; PI, phosphatidylinositol; PGL, phosphoglycolipid; PIDM, phosphatidylinositol dimannoside; GLs, glycolipids; PE, phosphatidylethanolamine; OH-PG, 2-hydroxy fatty acid containing phosphatidylglycerol; PL, phospholipid; ND, not determined.

major fatty acids are anteiso- $\mathrm{C}_{15: 0}$ and iso- $\mathrm{C}_{16: 0}$. Unsaturated menaquinones with 11 and 12 isoprene units are present. The polar lipids are diphosphatidylglycerol, phosphatidylglycerol, and dimannosyldiacylglycerol; an unknown monoglycosyldiacylglycerol and phosphoglycolipid are also present. The DNA base composition is $68.3 \mathrm{~mol} \% \mathrm{G}+\mathrm{C}$. Source: isolated from soil $(8,13)$.

The type strain is IFO 14592.

Description of Microbacterium aurum sp. nov. Microbacterium aurum (au'rum. L.n. aurum, gold). Good growth occurs on solid media in air; colonies are 1 to $2 \mathrm{~mm}$ in diameter, circular, low convex with entire margins, opaque, and moist. A golden yellow pigment is produced. In young cultures,

TABLE 4. Levels of DNA-DNA similarity among strains of the genus Microbacterium

\begin{tabular}{|c|c|c|c|c|c|}
\hline \multirow[b]{2}{*}{ Unlabeled DNA from: } & \multicolumn{5}{|c|}{ \% Similarity to labeled DNA from: } \\
\hline & $\begin{array}{c}\text { IFO } \\
14135^{\mathrm{T}}\end{array}$ & $\begin{array}{c}\text { IFO } \\
12610^{\mathrm{T}}\end{array}$ & $\begin{array}{l}\text { IFO } \\
3750^{\mathrm{T}}\end{array}$ & $\begin{array}{c}\text { IFO } \\
14592^{\mathrm{T}}\end{array}$ & $\frac{\text { IFO }}{15204^{\mathrm{T}}}$ \\
\hline M. lacticum IFO $14135^{\mathrm{T}}$ & 100 & 9 & 5 & 15 & 18 \\
\hline$M$. laevaniformans IFO $14471^{\mathrm{T}}$ & 4 & 7 & 8 & 14 & 24 \\
\hline M. imperiale IFO $12610^{\mathrm{T}}$ & 10 & 100 & 32 & 19 & 30 \\
\hline M. arborescens IFO $3750^{\mathrm{T}}$ & î & 29 & 100 & 18 & 26 \\
\hline M. dextranolyticum IFO $14592^{\mathrm{T}}$ & 7 & 7 & 15 & 100 & 43 \\
\hline M. aurum IFO $15204^{\mathrm{T}}$ & $\mathrm{ND}^{a}$ & 7 & 13 & 8 & 100 \\
\hline
\end{tabular}

${ }^{a} \mathrm{ND}$, not determined. small, slender rods are formed. Many cells are arranged at angles, forming V shapes; primary branching is uncommon. In older cultures rods are shorter, but a marked rod-coccus growth cycle does not occur. Gram-positive rods that are not acid fast and not motile. Endospores are not formed. The optimum growth temperature is ca. $30^{\circ} \mathrm{C}$. Acid is produced weakly from glucose, mannose, fructose, maltose, cellobiose, mannitol, galactose, L-rhamnose, sucrose, trehalose, raffinose, starch, and inulin, but not from D-xylose, L-arabinose, D-arabinose, glycerol, arbutin, esculin, salicin, ethanol, butanol, melibiose, melezitose, ribose, L-sorbose, xylitol, erythritol, adonitol, dulcitol, sorbitol, inositol, methanol, and $\alpha$-methyl-D-glucoside. Acetate, $\alpha$-ketoglutarate, and succinate are assimilated, but pyruvate, lactate, malate, maleate, formate, butyrate, oxalate, pimelate, glycolate, glyoxylate, gluconate, propionate, and hippurate are not assimilated. Esculin, starch, and Tween 60 are hydrolyzed, but Tween 20, Tween 40, Tween 80, and gelatin are not hydrolyzed. Urease negative. $\mathrm{H}_{2} \mathrm{~S}$ is produced. Voges-Proskauer reaction negative. Arginine is not decarboxylated.

The cell wall peptidoglycan contains lysine as the diamino acid (variation B1 $\beta$ ). The glycan moiety of the wall contains glycolyl and acetyl residues. The cell wall sugars are fucose, galactose, and glucose. Mycolic acid is not present. The nonhydroxylated fatty acids are primarily anteiso- and isomethyl branched acids. The major fatty acids are anteiso$\mathrm{C}_{15: 0}$, anteiso- $\mathrm{C}_{17: 0}$, and iso- $\mathrm{C}_{16: 0}$. Unsaturated menaquinones with 11 and 12 isoprene units are present. The polar 
TABLE 5. Differential characteristics of Microbacterium species ${ }^{a}$

\begin{tabular}{|c|c|c|c|c|c|c|}
\hline Characteristic & $\begin{array}{l}\text { M. lacticum } \\
\text { IFO } 14135^{\mathrm{T}}\end{array}$ & $\begin{array}{l}\text { M. laevaniformans } \\
\text { IFO } 14471^{\mathrm{T}}\end{array}$ & $\begin{array}{l}\text { M. dextranolyticum } \\
\text { IFO } 14592^{\mathrm{T}}\end{array}$ & $\begin{array}{l}\text { M. imperiale } \\
\text { IFO } 12610^{\mathrm{T}}\end{array}$ & $\begin{array}{l}\text { M. arborescens } \\
\text { IFO } 3750^{\mathrm{T}}\end{array}$ & $\begin{array}{l}\text { M. aurum } \\
\text { IFO } 15204^{T}\end{array}$ \\
\hline Color of colonies & Yellow & Yellow & Yellow & Orange & Orange & Yellow \\
\hline Motility & $\overline{-}$ & - & - & & & \\
\hline Growth on nutrient agar & Good & Good & Good & Poor & Poor & Poor \\
\hline $\begin{array}{l}\text { Growth at } 37^{\circ} \mathrm{C} \\
\text { Hydrolysis of: }\end{array}$ & - & + & - & + & - & + \\
\hline $\begin{array}{l}\text { Hyarolysis or: } \\
\text { Gelatin }\end{array}$ & - & + & - & - & + & + \\
\hline Starch & + & + & - & + & - & + \\
\hline Tween 20 & - & - & + & - & - & - \\
\hline Tween 40 & - & - & + & - & - & - \\
\hline Tween 60 & - & - & + & - & - & $\mathbf{w}$ \\
\hline Tween 80 & - & - & + & - & - & - \\
\hline $\mathrm{H}_{2} \mathrm{~S}$ formation & - & + & + & + & + & + \\
\hline Voges-Proskauer reaction & - & + & + & - & - & - \\
\hline Decarboxylation of arginine & - & + & - & - & - & - \\
\hline \multicolumn{7}{|l|}{ Acid produced from: } \\
\hline D-Xylose & - & - & + & + & + & - \\
\hline L-Arabinose & - & - & + & + & + & - \\
\hline Sucrose & - & + & + & + & + & + \\
\hline Trehalose & - & + & + & + & $\mathbf{w}$ & + \\
\hline Raffinose & - & + & + & + & - & + \\
\hline Melezitose & - & - & + & - & + & - \\
\hline Inulin & - & - & + & - & - & + \\
\hline \multicolumn{7}{|l|}{ Assimilation of: } \\
\hline Acetate & + & + & - & + & + & + \\
\hline Lactate & + & + & - & + & - & - \\
\hline Malate & + & + & - & + & - & - \\
\hline Fumarate & + & + & + & + & + & - \\
\hline Propionate & + & + & - & - & - & - \\
\hline \multicolumn{7}{|l|}{ Polar lipids } \\
\hline Phosphoglycolipid & + & - & + & - & - & - \\
\hline Glycolipid(s) & Multiple & Multiple & Multiple & Single & Single & Single \\
\hline 6-Deoxyhexose in cell walls & Rhamnose & Rhamnose & 6-Deoxytalose & Rhamnose & 6-Deoxytalose & Fucose \\
\hline Peptidoglycan type & $\mathrm{B} 1 \alpha$ & $\mathrm{B} 1 \alpha$ & $\mathrm{B} 1 \alpha$ & $\mathbf{B} 1 \boldsymbol{\beta}$ & $\mathrm{B} 1 \beta$ & $\mathbf{B} 1 \beta$ \\
\hline
\end{tabular}

${ }^{a}+$, positive; -, negative; $w$, weak.

lipids are diphosphatidylglycerol, phosphatidylglycerol, and dimannosyldiacylglycerol. The DNA base composition is $69.2 \mathrm{~mol} \% \mathrm{G}+\mathrm{C}$. Source: isolated from commercially available corn steep liquor.

The type strain is IFO 15204.

\section{ACKNOWLEDGMENTS}

We thank Toru Hasegawa and Masao Takeuchi, Institute for Fermentation, Osaka, for their support and discussions.

\section{REFERENCES}

1. Collins, M. D., D. Jones, and R. M. Kroppenstedt. 1983. Reclassification of Brevibacterium imperiale (Steinhaus) and "Corynebacterium laevaniformans"' (Dias and Bhat) in a redefined genus, Microbacterium (Orla-Jensen, as Microbacterium imperiale comb. nov. and Microbacterium laevaniformans nom. rev., comb. nov. Syst. Appl. Microbiol. 4:65-78.

2. Cowan, S. T., and K. J. Steel. 1965. Manual for the identification of medical bacteria. Cambridge University Press, London.

3. Ezaki, T., Y. Hashimoto, and E. Yabuuchi. 1989. Fluorometric deoxyribonucleic acid-deoxyribonucleic acid hybridization in microdilution wells as an alternative to membrane filter hybridization in which radioisotopes are used to determine genetic relatedness among bacterial strains. Int. J. Syst. Bacteriol. 39:224-229.

4. Harper, J. J., and G. H. G. Davis. 1979. Two-dimensional thin-layer chromatography for amino acid analysis of bacterial cell walls. Int. J. Syst. Bacteriol. 29:56-58.

5. Imai, K., M. Takeuchi, and I. Banno. 1984. Reclassification of "Flavobacterium arborescens" (Frankland and Frankland)
Bergey et al. in the genus Microbacterium (Orla-Jensen) Collins et al., as Microbacterium arborescens comb. nov., nom. rev. Curr. Microbiol. 11:281-284.

6. Jones, D., and M. D. Collins. 1986. Irregular, non-sporing gram-positive rods, p. 1261-1434. In P. H. A. Sneath, N. S. Mair, M. E. Sharpe, and J. G. Holt (ed.), Bergey's manual of systematic bacteriology, vol. 2. The Williams \& Wilkins Co., Baltimore.

7. Kandler, O., and H. König. 1978. Chemical composition of the peptidoglycan-free cell walls of methanogenic bacteria. Arch. Microbiol. 118:141-152.

8. Kobayashi, M., Y. Mitsuishi, and K. Matsuda. 1978. Pronounced hydrolysis of highly branched dextrans with a new type of dextranase. Biochem. Biophys. Res. Commun. 80:306-312.

9. Mesbah, M., U. Premachandran, and W. B. Whitman. 1989. Precise measurement of the $\mathrm{G}+\mathrm{C}$ content of deoxyribonucleic acid by high-performance liquid chromatography. Int. J. Syst. Bacteriol. 39:159-167.

10. Mikami, H., and Y. Ishida. 1983. Post-column fluorometric detection of reducing sugars in high-performance liquid chromatography using arginine. Bunseki Kagaku 32:E207-E210.

11. Minnikin, D. E., L. Alshamaony, and M. Goodfellow. 1975. Differentiation of Mycobacterium, Nocardia and related taxa by thin-layer chromatographic analysis of whole-organism methanolysates. J. Gen. Microbiol. 88:200-206.

12. Minnikin, D. E., M. D. Collins, and M. Goodfellow. 1979. Fatty acid and polar lipid composition in the classification of Cellulomonas, Oerskovia and related taxa. J. Appl. Bacteriol. 47:8795.

13. Mitsuishi, Y., M. Kobayashi, and K. Matsuda. 1979. Dextran $\alpha-1,2$ debranching enzyme from Flavobacterium sp. M-73: its 
production and purification. Agric. Biol. Chem. 43:2283-2290.

14. National Collection of Food Bacteria. 1986. Catalogue of strains. AFRC Institute of Food Research Reading Laboratory, Reading, England.

15. Orla-Jensen, S. 1919. The lactic acid bacteria. Host and Son, Copenhagen.

16. Saito, H., and K. Miura. 1963. Preparation of transforming deoxyribonucleic acid by phenol treatment. Biochim. Biophys. Acta 72:619-629.

17. Schleifer, K. H. 1970. Die Mureintypen in der Gattung Microbacterium. Arch. Mikrobiol. 71:271-282.

18. Schleifer, K. H., and O. Kandler. 1972. Peptidoglycan types of bacterial cell walls and their taxonomic implications. Bacteriol. Rev. 36:407-477.
19. Suzuki, K., and K. Komagata. 1983. Taxonomic significance of cellular fatty acid composition in some coryneform bacteria. Int. J. Syst. Bacteriol. 33:188-193.

20. Takeuchi, M., and A. Yokota. 1989. Cell-wall polysaccharides in coryneform bacteria. J. Gen. Appl. Microbiol. 35:233-252.

21. Takeuchi, M., and A. Yokota. 1991. Reclassification of strains of Flavobacterium-Cytophaga group in IFO Culture Collection. Inst. Ferment. Res. Commun. (Osaka) 15:83-96.

22. Uchida, K., and K. Aida. 1977. Acyl type of bacterial cell wall: its simple identification by a colorimetric method. J. Gen. Appl. Microbiol. 23:249-260.

23. Wako Pure Chemical Industries, Ltd. 1989. Technical note on the system of PTC-amino acid analysis. Wako Pure Chemical Industries, Ltd., Osaka, Japan. (In Japanese.) 